Niepełnosprawność. Dyskursy pedagogiki specjalnej

\title{
Aleksandra Hulewska
}

Zakład Nauk Humanistycznych, Uniwersytet Przyrodniczy we Wrocławiu

\section{Rola mediów społecznościowych w edukowaniu o niepełnosprawności - raport z badań}

\begin{abstract}
Artykuł podejmuje zagadnienie potrzeby edukowania o niepełnosprawności zarówno w celu poszerzania wiedzy odbiorców na temat tego zjawiska, jak i osłabiania stereotypów oraz uprzedzeń społecznych wobec osób z niepełnosprawnościami. Autorka sformułowała hipotezę głosząca, iż rozwój nowoczesnych technologii informacyjnych, a w szczególności-mediów społecznościowych, może przyczynić się do poszerzenia świadomości polskich studentów na temat niepełnosprawności. W celu zweryfikowania powyższej hipotezy zaprojektowano badania empiryczne. Niniejsze opracowanie zostało poświęcone omówieniu metodologii badań oraz zaprezentowaniu uzyskanych rezultatów.
\end{abstract}

Słowa kluczowe: social media, komunikacja społeczna, stereotypy i uprzedzenia wobec osób z ograniczoną sprawnością, edukowanie o niepełnosprawności

\section{The role of social media in the process of educating about disability}

This paper is an attempt to discuss the need of educating about disability, either in order to increase the knowledge about this phenomenon or to eliminate the persistent social stereotypes and prejudices towards people with disabilities, which have been held in contemporary societies. The authoress formulates the hypothesis that development of the new information technologies and in particular - the social media - can raise the Polish students' awareness of disability. In order to verify the above hypothesis an empirical study was conducted. The methodology of the research and the obtained results are presented in the article.

Keywords: social media, social communication, stereotypes and prejudices against people with disabilities, educating about disability

\section{Wprowadzenie - cel podjętych badań}

Badania na temat postaw wobec osób niepełnosprawnych często ujawniają brak spójności pomiędzy wyrażanymi werbalnie opiniami a rzeczywistym nastawieniem respondentów [Kossewska 2003]. Deklaracje ustne są zazwyczaj wyrazem społecznych konwenansów (których źródłem jest m.in. potrzeba aprobaty 
społecznej) oraz przejawem lęku przed negatywną oceną ze strony otoczenia. Dość często maskują one nieprzychylne, a wręcz wrogie postawy rzeczywiste, czyli uprzedzenia społeczne [Kossewska 2003]. Przyczyną negatywnych postaw jest najczęściej brak wiedzy i wynikające z nich stereotypowe postrzeganie osób niepełnosprawnych [Kowalik 2007, s. 68].

Przykładowo, badania prowadzone wśród młodzieży wskazują na niski poziom wiedzy o przyczynach niepełnosprawności, osobach niepełnosprawnych i ich możliwościach, czemu towarzyszy znaczne wyolbrzymianie ograniczeń wynikających z niepełnej sprawności [Konarska 1994; Oszustowicz 1995]. Badania realizowane wśród pracodawców również ujawniają rozmaite lęki związane z zatrudnieniem osób z ograniczoną sprawnością, którym towarzyszy brak lub złe rozeznanie w kwestiach związanych z umiejętnościami i kwalifikacjami osób niepełnosprawnych, stereotypowe przekonanie o większej chorobowości i większej wypadkowości tej grupy osób [Woźniak 2007, s. 69-84]. Owocuje to sytuacją, w której rzeczywiste wskaźniki zatrudnienia osób niepełnosprawnych w polskich przedsiębiorstwach są niższe niż deklarowana chęć zatrudnienia osoby niepełnosprawnej (która także jest stosunkowo niska) [Woźniak 2007, s. 82]. Niewystarczająca wiedza wraz z tendencją do opierania się na stereotypach w myśleniu o osobach niepełnosprawnych skutkuje uprzedzeniami i różnymi formami dyskryminowania tej grupy osób [Kowalik 2007, s. 69]. Wszystko powyższe wskazuje na istnienie pilnej potrzeby edukowania społeczeństwa na temat niepełnosprawności w celu wyeliminowania, a przynajmniej częściowego ograniczenia tych niekorzystnych zjawisk [Hulewska 2014].

Podstawą procesu uczenia się i nauczania jest komunikowanie [Woynarowska 2008, s. 154]. W świetle definicji Bogusławy Dobek-Ostrowskiej: „komunikowanie jest procesem porozumiewania się jednostek, grup lub instytucji. Jego celem jest wymiana myśli, dzielenie się wiedzą, informacjami i ideami. Proces ten odbywa się przy użyciu zróżnicowanych środków i wywołuje określone skutki" [Dobek-Ostrowska 2004, s. 13]. Ważnym środkiem wykorzystywanym w procesie edukacji są media masowe [McQuail 2007]. Jak zauważa Janusz Gajda: „Rola mediów w życiu społecznym, a w tym i edukacji, zwłaszcza równoległej, wciąż rośnie. To one stanowią główne źródło informacji o otaczającym świecie, kreują obraz współczesnej kultury, wytyczają zakres kontaktów z nią, kształtują upodobania i postawy" [Gajda 2004, s. 63]. Będąc świadomym zagrożeń J. Gajda wskazuje na szanse edukacyjnego wykorzystania mass mediów. Upatruje ich m.in. w możliwości realizacji wszelkiego rodzaju edukacji zarówno w wymiarze edukacji instytucjonalnej (szkolnej), jak i równoległej i ustawicznej (poszkolnej). Jednocześnie autor słusznie zauważa, że współcześnie - poza programami edukacyjnymi intencjonalnie skierowanymi do uczących się - w mediach coraz częściej można 
znaleźć inne treści, np. o charakterze poradnikowym, z których odbiorcy mogą czerpać wiedzę na interesujące ich tematy [Gajda 2004, s. 66].

Ostatnia dekada to dynamiczny rozwój tzw. nowych mediów [Lister, Dovey, Giddings, Grant, Kelly 2009]¹. Internet jest dziś coraz częściej wykorzystywany jako nośnik przekazów edukacyjnych. W opinii Krzysztofa Puchalskiego sieć WWW poszerza dotychczasowe możliwości komunikacyjne (szybkość, zasięg) i otwiera nowe (interakcja, wirtualne wspólnoty), które przeobrażają dotychczasową praktykę edukacyjną [Puchalski 2012, s. 119-139]. Kluczową sprawą dla możliwości korzystania z różnych źródeł informacji w Internecie jest jego dostępność. Jak wynika z raportu „Internauci 2014”2 , od 2010 roku użytkownicy sieci stanowią w Polsce ponad połowę ogółu dorosłych. W kwietniu 2014 roku korzystanie $\mathrm{z}$ internetu przynajmniej raz w tygodniu zadeklarowało niemal dwie trzecie badanych (63\%). Prawie wszyscy użytkownicy (98\%) mają w domu dostęp do sieci. Od kilku lat obserwuje się wzrost popularności internetu bezprzewodowego, z którego korzysta ponad trzy czwarte użytkowników (77\%).

Wraz z rosnącą liczbą internautów powiększa się również grono osób korzystających z mediów społecznościowych. Zdaniem Clary Shih: „rewolucja społecznościowa w Internecie trwa już w najlepsze" [Shih 2012, s. 31]. Dla wielu osób social media są pierwszym miejscem, do którego wchodzą w sieci. Użytkownicy często uzależniają dalsze przeszukiwanie i przeglądanie sieci od treści, które pojawią się w tych serwisach. Social media to dla wielu "drzwi do całego Internetu” [Shih 2012, s. 31]. Potwierdzają to liczby. Według raportu „We are social” ${ }^{3}$ z mediów społecznościowych korzysta obecnie ponad 2 miliardy osób, co oznacza, że w ciągu jednego roku przybyło 222 miliony nowych użytkowników. W Polsce konto w jednym z serwisów społecznościowych w roku 2008 posiadało $21 \%$ Polaków, a w 2014 - już 39\%. Lawinowo rosnąca popularność social media, z których korzystają głównie ludzie młodzi, rodzi pytanie o ich walory edukacyjne - w tym wypadku: w zakresie edukowania o niepełnosprawności. W celu ustalenia, czy i w jakim zakresie social media mogą przyczyniać się do wzrostu wiedzy użytkowników o niepełnosprawności, zrealizowano badania empiryczne, których prezentacji i omówieniu zostały poświęcone kolejne części artykułu.

1 Wspomniani autorzy definiują nowe media jako: „wszystkie te metody i praktyki społeczne związane z komunikowaniem się, reprezentacją i ekspresją, jakie rozwinęły się dzięki cyfrowemu, multimedialnemu, usieciowionemu komputerowi, jak również wszelkie innowacje, jakie za sprawą komputera zostały wprowadzone do innych mediów, począwszy od książki aż po film, od telefonu po telewizję [Lister, Dovey, Giddings, Grant, Kelly 2009, s. 2]

2 Internauci 2014, Komunikat z badań CBOS, nr 82, s. 1.

3 http://wearesocial.net/blog/2015/01/digital-social-mobile-worldwide-2015/ [dostęp: 11.04.2016]. 


\section{Metoda}

$\mathrm{W}$ badaniach zastosowano metodę zogniskowanego wywiadu grupowego, $\mathrm{tj}$. technikę badań jakościowych polegająca na pozyskiwaniu opinii grup osób na temat określonego produktu, idei, zjawiska itp. [Barbour 2011]. Badania zrealizowano w okresie: kwiecień-maj 2016, w 5 grupach. Każda z nich liczyła 10 osób. Wśród uczestników znalazło się 29 kobiet i 21 mężczyzn. Średnia wieku badanych wynosiła 21,5 lat. Żaden z respondentów nie posiadał orzeczenia o niepełnosprawności. 7 osób zadeklarowało, że zna osobiście co najmniej jedną osobę niepełnosprawną (krewny, przyjaciel, znajomy). W badaniach uczestniczyli studenci trzech wrocławskich uczelni - Uniwersytetu Wrocławskiego, Uniwersytetu Przyrodniczego oraz Politechniki Wrocławskiej. Wszyscy respondenci przyznali, że codziennie korzystają z Internetu, a także posiadają konto na co najmniej jednym z popularnych portali społecznościowych.

Jak nadmieniono wcześniej, głównym celem badań było rozstrzygnięcie następującego problemu - pytania badawczego: czy social media poszerzają zakres wiedzy użytkowników o zjawisku niepełnosprawności? W scenariuszu wywiadu zawarto ponadto szereg pytań szczegółowych dotyczących następujących kategorii tematycznych:

1) Media społecznościowe jako źródło wiedzy o niepełnosprawności.

2) Motywacja do poszukiwania wiedzy o niepełnosprawności w social media.

3) Rodzaje wiedzy o niepełnosprawności uzyskiwane w mediach społecznościowych.

4) Wpływ wiedzy o niepełnosprawności uzyskanej w social media na użytkowników.

5) Opinie badanych o możliwościach wykorzystania mediów społecznościowych $\mathrm{w}$ procesie edukowania o niepełnosprawności.

\section{Prezentacja i omówienie wyników}

Zgromadzony materiał został poddany analizie, która miała na celu wyłonienie kluczowych trendów przejawiających się w odpowiedziach uczestników badań na zawarte $\mathrm{w}$ scenariuszu pytania. Ujawnione tendencje zilustrowano przykładowymi wypowiedziami respondentów, które zacytowano w brzmieniu dosłownym, tj. nie korygowano ich gramatycznie, stylistycznie itp.

Pierwsza grupa pytań miała na celu ustalenie, czy social media są dla badanych źródłem wiedzy o niepełnosprawności. Analiza zgromadzonego materiału empirycznego wykazuje, że większości respondentów zdarza się uzyskiwać 
nowe, nieznane wcześniej informacje na temat niepełnosprawności w trakcie korzystania z mediów społecznościowych:

"Kilka razy trafitem na post o niepetnosprawnej osobie, mem poruszajacy problemy tych ludzi itp."; "Przeważnie pod koniec kwietnia na Facebooku pojawiaja się prośby o przekazanie 1\% podatku na sprzęt dla niepetnosprawnych dzieci, na leczenie, rehabilitację itp."

Jednocześnie okazuje się, że uczestnicy badań uzyskują wiedzę o niepełnosprawności z mediów społecznościowych sporadycznie, podobnie jak sporadycznie pozyskują tego rodzaju informacje z innych źródeł:

"Szczerze mówiąc, to nie jestem jakoś specjalnie zainteresowany tematem niepetnosprawności"; "Wstyd się przyznać, ale w ogóle rzadko szukam czegoś... rzadko szukam jakichś szczegótów czy danych o ludziach niepetnosprawnych"

Zdecydowana mniejszość respondentów czerpie wiedzę o niepełnosprawności z social media regularnie:

„Jakiś czas temu trafitam na świetny blog podróżniczy prowadzony przez sparaliżowanego mężczyznę. Bardzo fajnie opisuje w nim, jak na wózku zwiedza różne miejsca na świecie. Subskrybuję go do dziś".

Niektórzy respondenci nie potrafili przypomnieć sobie, z których konkretnie mediów społecznościowych dowiedzieli się czegoś nowego o niepełnosprawności. Pozostali wymieniali: Facebook, Instagram, YouTube, Naszą Klasę, Google+ , Allegro i Twitter. Zapytani o to, z których mediów (tradycyjnych czy nowych) najczęściej uzyskują wiedzę o niepełnosprawności, uczestnicy badań mówili przede wszystkim o nowych mediach (Internet). Rzadziej powoływali się na telewizję, broszury i ulotki, literaturę naukową i popularno naukową, prasę drukowaną, billboardy oraz radio. Poproszeni o wskazanie miejsc w Internecie, z których głównie czerpią wiedzę o niepełnosprawności, badani wymieniali przede wszystkim portale ogólnotematyczne, strony internetowe organizacji pozarządowych działających na rzecz osób niepełnosprawnych i - na 3 miejscu - media społecznościowe. Na pytanie, od kogo bezpośrednio pochodzą treści na temat niepełnosprawności, z którymi badani stykają się w social media, respondenci wymieniali przede wszystkim swoich znajomych:

„Nie mam czasu śledzić wszystkiego, co się dzieje na Facebooku. Obserwuje tylko niektórych znajomych. Jak oni udostępniają u siebie coś, co przykładowo ma zwiazek z niepetnosprawnościa, to przeważnie rzucam na to okiem", "Ostatnio znajomy polecit mi na YouTube filmik jednego niepetnosprawnego mówcy motywacyjnego. Zrobił na mnie duże wrażenie".

Część badanych wskazywała ponadto na subskrybowane przez siebie kanały: „Mam w ulubionych fundację Anny Dymnej 'Mimo wszystko'", "Czytam bloga 'moimioczami.pl'", 
a także główny strumień treści w danym portalu:

"Czasem, zaraz po zalogowaniu się na Facebooka, trafiam na jakiś post o osobach niepetnosprawnych".

Druga kategoria pytań badała motywację respondentów do poszukiwania wiedzy o niepełnosprawności w mediach społecznościowych. Jak się okazuje, większość badanych trafia w social media na informacje dotyczące niepełnosprawności przypadkiem. Ci, którym zdarza się z celowo poszukiwać tego rodzaju treści, deklarują, że skłaniają ich do tego rekomendacje znajomych:

"Znajomy polecit mi bardzo fajna stronkę na Facebooku o kampaniach społecznych. Tam dość często pojawiają się kampanie dotyczące osób niepetnosprawnych"

oraz chęć pogłębienia wiedzy o konkretnym przedsięwzięciu:

"Na uczelni zobaczyłam plakat '\#WroAccessible16' - byt tam podany adres ich Facebooka. Weszłam tam, żeby dowiedzieć się czegoś więcej o tej akcji”, "Koleżanka zamieścita u siebie post z prośbą o wsparcie dla niepetnosprawnego chtopaka. Zajrzałam na jego profil, żeby sprawdzić, kim on jest i czego potrzebuje. Prawdę mówiąc... chciałam sprawdzić, czy nie jest to fejk".

Jedna osoba jako powód poszukiwania treści związanych z niepełnosprawnością $\mathrm{w}$ mediach społecznościowych wskazała zadanie realizowane $\mathrm{w}$ trakcie studiów:

„Na zaliczenie mieliśmy przeanalizować kilka kampanii społecznych w social media".

Jak się okazuje, jeśli badani z własnej inicjatywy szukają informacji o niepełnosprawności $\mathrm{w}$ mediach społecznościowych, to najczęściej sięgają do treści zamieszczanych na fanpage'ach organizacji pozarządowych działających na rzecz osób z ograniczona sprawnością, a także zaglądają na profile i blogi prowadzone przez konkretną osobę niepełnosprawną. Warto podkreślić, że respondenci nie zawsze decydują się zapoznać ze szczegółami informacji o niepełnosprawności, na które trafiają przypadkiem. Motywuje ich do tego wspomniana już wcześniej rekomendacja znajomych, a także interesujący, przykuwający uwagę wygląd posta:

„Jak widzę ciekawe zdjęcie czy grafikę poświęcone problemom osób niepetnosprawnych, to na to klikam. Ale to musi być naprawdę dobrze zrobione - tak, że jestem tym od razu zaintrygowana $i$ chcę dowiedzieć się czegoś więcej".

Badani pomijają i/lub odrzucają treści mało wyraziste:

"Jeśli coś nie wyróżnia się z gaszczu innych postów, to się tym nie interesuje",

nachalne: 
"Przestaję śledzić tych, którzy w kótko wrzucają to samo, np. błagalne posty o pomoc dla kolejnej chorej osoby", "Drażni mnie natrętne wysyłanie zaproszeń na to samo wydarzenie",

a także oceniane jako zbyt drastyczne:

"Nie jestem w stanie ogladać zdjęć zdeformowanych ciał. Po prostu jestem na to zbyt wrażliwa".

Większości respondentów przynajmniej raz zdarzyło się podzielić treściami o niepełnosprawności pozyskanymi w social media $\mathrm{z}$ innymi użytkownikami danego serwisu. Skłaniała ich do tego głównie motywacja altruistyczna:

"Kiedyś bardzo poruszyła mnie historia rodziców zbierających na rehabilitację swojej córeczki. Chciałam pomóc tej dziewczynce, więc puściłam informację dalej",

a także chęć podzielenia się ze znajomymi treściami uznawanymi za szczególnie inspirujące i/lub ciekawe:

„Ostatnio trafiłem na świetny piktogram pokazujacy, jakie dyscypliny będa reprezentowane na paraolimpiadzie w Rio. Był na tyle ciekawy i fajnie zaprojektowany, że udostępnitem go na swojej tablicy".

Kolejna grupa pytań odnosiła się do rodzajów wiedzy o niepełnosprawności, którą badani zdobywają za pośrednictwem social media. Odpowiedzi respondentów wskazują przede wszystkim na informacje o kampaniach i akcjach społecznych realizowanych na rzecz osób niepełnosprawnych:

"Często na Allegro spotykam się z aukcjami mającymi na celu pomoc jakiejś niepetnosprawnej osobie",

a także na dane o organizacjach zrzeszających osoby niepełnosprawne i/lub działające na rzecz poprawy sytuacji tych osób w Polsce:

"Z Facebooka dowiedziałam się o Fundacji 'Integralia'. Lubię tam czasem zaglądać, bo zamieszczają ciekawe, dające do myślenia posty".

Poza tym, w odpowiedziach badanych często pojawiały się historie konkretnych osób niepełnosprawnych, które poznali za pośrednictwem ich blogów czy publicznych profili na Facebooku, Twitterze itp.:

"Znajoma udostępnita kiedyś u siebie link do bloga studentki z porażeniem mózgowym. Weszłam na niego i bardzo spodobato mi się to, jak dziewczyna opisuje swoje życie, swoje problemy, przeszkody, z jakimi musi się na co dzień zmagać i jak je pokonuje... Ale też to, co ja interesuje, na przykład książi czy filmy, jak spędza święta czy wolny czas... Od tamtej pory odwiedzam jej blog regularnie. Inspiruje mnie, jest też świetnym antidotum na chandrę. Bo skoro ona mimo takich trudności daje radę, to ja nie powinnam marudzić...".

W opinii respondentów głównym celem przekazów o niepełnosprawności w social media jest, po pierwsze: przekonywanie do udzielenia pomocy osobom niepełnosprawnym: 
„Posty, na które trafiam, głównie dotycza tego, co my... że tak powiem... ludzie zdrowi możemy zrobić, by pomóc jakiejś konkretnej osobie niepetnosprawnej albo organizacji. Na przykład przekazać $1 \%$ podatku",

i - po drugie, informowanie:

„...pokazuja, czym jest niepetnosprawność, jak się żyje z określona przypadtościa, na jakie bariery taka osoba napotyka, czego potrzebuje, dajmy na to, od urzędników, architektów czy pracodawców, ale też od nas wszystkich, żeby żyło się jej normalniej".

Jednocześnie, zdaniem uczestników badań, na najbardziej wartościowe z edukacyjnego punktu widzenia treści można trafić w social media na profilach organizacji wspierających osoby niepełnosprawne oraz na blogach prowadzonych przez osoby niepełnosprawne i/lub na publicznych profilach tych osób na Facebooku. Na pytanie, czy respondenci mają poczucie, że media społecznościowe przyczyniły się do poszerzenia ich wiedzy o zjawisku niepełnosprawności, większość badanych odpowiedziała twierdząco.

Pytania z następnej, czwartej, kategorii dotyczyły wpływu wiedzy o niepełnosprawności zaczerpniętej z social media na użytkowników. W opinii badanych wiedza o niepełnosprawności, którą uzyskali za pośrednictwem mediów społecznościowych, przede wszystkim uczuliła ich na to, z jakimi problemami spotykają się na co dzień konkretne osoby niepełnosprawne oraz jak sobie z nimi radzą:

„Jej blog uzmystowit mi, że ona musi przeznaczyć dwa razy więcej czasu na każda codzienna czynność, na głupie umycie zębów czy zrobienie sobie kawy”, "Nie wiedziałam, że ludzie głuchoniemi też maja problemy ze znalezieniem pracy".

Respondenci mówili także o inspiracji - w zakresie zmiany myślenia o sobie i o własnym życiu:

"Kiedy zobaczyłem, jak on ma ciężko... cholernie ciężko..., zdałem sobie sprawę z tego, że ja nie mam prawa narzekać",

mobilizacji do podjęcia pracy nad sobą:

"Skoro oni potrafia codziennie trenować, to ja też mogę. Tak sobie powiedziatem dwa lata temu, jak trafitem na YouTube na filmik o paraolimpijczykach. Od tamtej pory regularnie biegam".

Część respondentów poczuła się zachęcona do zaangażowania się w konkretną akcje mającą na celu pomoc osobom niepełnosprawnym:

„Udało mi się namówić rodziców, żeby wpłacili $1 \%$ podatku na jedna fundację opiekująca się niepetnosprawnymi dziećmi".

Niektórzy wskazywali też na pozytywne zmiany w postrzeganiu osób z ograniczoną sprawnością: 
„Wcześniej myślatem, że tacy ludzie to ofiary, które potrafią tylko jęczeć o pomoc, ale niczego nie robia. Ale jak znajoma podestała mi link do filmiku o tym gościu bez rąk i nóg... Nick-chyba tak ma na imię... - on ptywa, surfuje, gra w golfa... i jeszcze jeździ po całym świecie ze swoimi wykładami. Wtedy dotarło do mnie, że się myliłem... że wielu z tych ludzi to bohaterowie".

Zaledwie 2 osoby przyznały, że informacje o niepełnosprawności uzyskane $\mathrm{w}$ social media zachęciły je to do poszukiwania dodatkowej wiedzy w innych źródłach, tj. w książkach i na stronach internetowych organizacji działających na rzecz osób z ograniczoną sprawnością.

Ostatnia grupa pytań badała opinie respondentów na temat możliwości wykorzystania mediów społecznościowych w procesie edukowania o niepełnosprawności. Zdaniem większości badanych sociel media są użytecznym źródłem wiedzy o niepełnosprawności. Po pierwsze, w zakresie informowania o konkretny akcjach mających na celu pomoc osobom niepełnosprawnym:

"Koleżanka udostępniła u siebie ciekawy rysunek. Na pierwszy rzut oka były tam biegajace zdrowe dzieci. Dopiero kiedy przyjrzałam się mu bliżej, zobaczyłam, że każde z tych dzieci jest niepetnosprawne... Jedno bez ręki, inne na wózku, jeszcze inne z zawiązanymi oczami... Z jednej strony mnie to zszokowało, a z drugiej - zaintrygowato. Zaraz weszłam na fanpage, z którego pochodzit ten rysunek. I tak trafitam na świetnq akcję: 'Maciek biega'. Bardzo mi się podoba to, co robiq".

Po drugie, respondenci widzą w zamieszczanych w social media treściach dotyczących niepełnosprawności cenne źródło inspiracji w zakresie rozwoju osobistego:

„Voujcic uzmysłowił mi, że największe ograniczenia tkwia w naszych głowach. Jego posty na Facebooku codziennie mi to przypominaja".

Uzyskany materiał empiryczny prowadzi do wniosku, że media społecznościowe są traktowane przez badanych nie tyle jako źródło specjalistycznych danych o ogólnym zjawisku, jakim jest niepełnosprawność, ile jako zasób wiedzy o subiektywnych przeżyciach konkretnych osób zmagających się z określonym upośledzeniem czy schorzeniem:

"Wiedzę typowo medyczna mogę sobie znaleźć w encyklopedii. Ale w żadnej encyklopedii czy w podręczniku nie znajdę tego, co daje mi czytanie bloga tej dziewczyny. Nie dowiem się z nich, jak ona żyje, co ją cieszy i martwi, z czym się mierzy, jaki jest jej śrwiat".

Na pytanie o to, czego w tej chwili brakuje w social media w zakresie skutecznego edukowania o niepełnosprawności, badani odpowiedzieli, że ciekawych infografik, które w skondensowanej i przystępnej formie ilustrowałyby dany problem:

"Może gdybym trafit na dobrze zrobiona infografikę, to bardziej zainteresowałbym się problemem. W Stanach jest tego mnóstwo, w Polsce praktycznie w ogóle się z czymś takim nie spotkatem". 
Jednocześnie kilkoro respondentów deklarowało przesyt treściami mającymi na celu skłonienie innych do udzielenia pomocy osobom niepełnosprawnym:

"Przestatem śledzić znajomych, którzy bez przerwy wrzucają coś o niepetnosprawnych ludziach, biednych zwierzętach itp. Rozumiem, że trzeba im pomagać, ale jak jest tego za dużo, to mnie to odrzuca".

\section{Zakończenie}

Jak zauważa Zbigniew Woźniak: „W zbyt wielu obszarach życia społecznego wciąż utrzymują się zjawiska, procesy i postawy sprzyjające dewaluacji pozycji osób z niesprawnością, ograniczaniu ich praw obywatelskich, deprecjonowaniu roli w życiu zbiorowym poprzez redukowanie problemu niepełnej sprawności do kosztów ekonomicznych i aktywności zawodowej osób z niesprawnością. Pozostaje to w sprzeczności z rzeczywistymi potrzebami ludzi z ograniczeniami funkcjonalnymi - niepełna sprawność oraz jej skutki jednostkowe i zbiorowe są produktem 'niesprawnego środowiska'" [Woźniak 2010, s. 81]. Ważnym procesem, który - w opinii autorki niniejszego artykułu - może przeciwdziałać tym niekorzystnym zjawiskom, jest edukowanie o niepełnosprawności. Dzięki edukacji wiedza niekompletna i oparta na stereotypowych uproszczeniach miałaby szansę przeobrazić się $\mathrm{w}$ pełniejsze zrozumienie osób niepełnoprawnych - ich problemów, bolączek, barier, które muszą na co dzień pokonywać, a także - co jest niezmiernie ważne z perspektywy integracji -ich indywidualnych właściwości, aspiracji i zdolności, którymi nie różnią się od innych ludzi.

Wyniki zaprezentowanych badań prowadzą do wniosku, że social media mają $\mathrm{w}$ sobie potencjał edukowania o niepełnosprawności. Bo chociaż tylko nieliczni respondenci poszukują na własną rękę wiedzy o niepełnosprawności na portalach społecznościowych (podobnie jak niewielu z nich intencjonalnie poszukuje takiej wiedzy w tradycyjnych źródłach), to jednocześnie większość badanych przyznaje, że zdarza się im uzyskiwać nowe, nieznane wcześniej informacje na temat niepełnosprawności za pośrednictwem tego kanału. Wiedza ta pochodzi przede wszystkim od znajomych udostępniających interesujące treści na swoich profilach. Rezultat ten ilustruje jedną z naczelnych zasad funkcjonowania social media, jaką jest wspólnotowość [Celiński 2009, s. 263; Levinson, 2010]. Użytkownicy mediów społecznościowych bez przerwy wymieniają się z innymi rozmaitymi treściami, co napędza niekończący się łańcuch - a w zasadzie: sieć - wzajemnych interakcji. Od czasu do czasu przedmiotem tej wymiany stają się posty, memy i inne "wytwory" odnoszące się do problematyki osób z ograniczoną sprawnością. Jak się okazuje, części z tych treści - przede wszystkim dzięki rekomendacjom 
znajomych - udaje się nie tylko przykuć uwagę, ale także istotnie wpłynąć na myślenie i działanie odbiorców.

Uzyskany $\mathrm{w}$ badaniach materiał pokazuje ponadto, że dzięki mediom społecznościowym respondenci poszerzają swoją wiedzę o niepełnosprawności przede wszystkim w dwóch obszarach. Po pierwsze, zdobywają nowe informacje o akcjach organizowanych na rzecz osób z ograniczoną prawnością. Wiedza ta wpisuje się w obecny od dawna w mediach (tradycyjnych i nowych) trend "charytatywny", który z jednej strony pozwala udzielić niepełnosprawnym konkretnego wsparcia, z drugiej jednak strony - przyczynia się do utrwalania niekorzystnego obrazu tej grupy jako tych, którzy wyłącznie zależą od dobrej woli innych [Ruść 2007, s. 136]. Druga kategoria wiedzy o niepełnosprawności, którą badani pozyskują $\mathrm{w}$ social media, to informacje o życiu konkretnych osób z ograniczoną sprawnością, którymi ci dzielą się z otoczeniem pisząc blogi czy prowadząc publiczne profile w portalach społecznościowych. Dzięki nim użytkownicy Internetu mają możliwość poznać niepełnosprawność nie tyle z perspektywy ogólnych statystyk i bezosobowych faktów, ile - z perspektywy konkretnego człowieka, który żyjąc w określonym kontekście doświadcza specyficznych dla siebie barier, a także swój jedyny i niepowtarzalny sposób próbuje przekraczać ograniczenia wynikające z niepełnej sprawności. Na podstawie wyników referowanych badań można stwierdzić, że takie fenomenologiczne [Bugental 1978] (w odróżnieniu od pozytywistycznego) poznanie osoby niepełnosprawnej $-w$ jej jedynym w swoim rodzaju sposobie-bycia-w-swiecie [Hall, Lindzey 1994, s. 310-317] sprzyja rozwojowi nastawień empatycznych, a dzięki temu ułatwia wychodzenie poza stereotypy i klisze społeczne.

Powyższy rezultat ten można analizować odwołując się do modelu dualistycznego przetwarzania danych Marilynn Brewer [Brewer 1999, s. 209]. Badaczka wyróżniła dwa tory przetwarzania informacji o innych ludziach: kategorialny (przez pryzmat stereotypu) i spersonalizowany (przez pryzmat zindywidualizowanych informacji o konkretnej osobie). Model zakłada, że: „kiedy relacja pomiędzy spostrzegającym a osobą spostrzeganą charakteryzuje się silną orientacją interpersonalną, stereotypy nie są używane. Alternatywnym systemem odniesienia w spostrzeganiu jednostek stają się takie cechy, jak życzliwość, inteligencja czy towarzyskość" [Brewer 1999, s. 209]. Informacje o konkretnych osobach niepełnosprawnych, jakie badani czerpią z ich blogów czy profili na Facebooku itp., zdają się pełnić taką - personalizującą percepcję - funkcję. Znajduje to potwierdzenie w wypowiedziach, w których respondenci odnoszą się do konkretnego człowieka z ograniczoną sprawnością, a nie do całej grupy niepełnosprawnych osób. W opinii autorki niniejszego artykułu to właśnie w opisywanym efekcie - tj. zdolności do przekazywania informacji personalizujących o osobach niepełnosprawnych tkwi największa siła mediów społecznościowych. Nie dostarczają one użytkowni- 
kom uogólnionej (a więc - bezosobowej) wiedzy akademickiej na taką skalę, jak robią to tradycyjne podręczniki, literatura fachowa czy wywiady z ekspertami. Jednocześnie - ze względu na swoją specyfikę (w social media ludzie bez przerwy nawiązują ze sobą kontakty o charakterze mniej formalnym, bardziej otwarcie dzielą się z innymi informacjami o życiu prywatnym, a wreszcie - dzięki zdobyczom nowych technologii - mogą dotrzeć ze swoim przekazem do szerokiej rzeszy odbiorców) - w większym stopniu personalizują spostrzeganie i myślenie o osobach z ograniczoną sprawnością, niż czynią to media tradycyjne.

Powyższe założenia zdają się dodatkowo potwierdzać te wypowiedzi badanych, z których wynika, że zdobyta w social media wiedza o niepełnosprawności ma zdolność do wpływania na odbiorców. I nie jest to wyłącznie wpływ o charakterze informacyjnym (przyrost wiedzy, zmiana optyki patrzenia), ale także motywacyjnym. Ten ostatni przejawia się we wzbudzaniu motywacji do podjęcia określonych działań na rzecz osób niepełnosprawnych i - co szczególnie interesujące - mobilizacji do podjęcia pracy nad sobą i rozwoju osobistego (czerpanie przykładu z osób z ograniczoną sprawnością). Można więc pokusić się o sformułowanie tezy, że zdobyta w social media wiedzo o niepełnosprawności - choć pozyskiwana nieintencjonalnie i dość fragmentaryczna - jest zasobem, który nie tylko uczy, ale także, a może przede wszystkim: inspiruje. Oczywiście jest to konkluzja, którą należy traktować z dużą ostrożnością - raczej jako punkt wyjścia do dalszych, pogłębionych dociekań i analiz, niż jako ustalenie o charakterze ostatecznym.

Na zakończenie warto przywołać fragment tekstu Tomasza Gobana-Klasa pt. „Pokolenie SMS-u w rozwiniętym społeczeństwie informacyjnym" [Goban-Klas 2011, s. 226; 231-232]: „Dla katechetów, pedagogów, nauczycieli akademickich, a także dla policjantów, sędziów sądów dla nieletnich, w istocie dla wszystkich tych, którzy mają roboczy kontakt z dzisiejszą młodzieżą, staje się powoli oczywiste, że dorasta nowe pokolenie ludzi młodych. (...) Jak wynika z wielu badań (...) współcześni młodzi ludzie:

1. To pokolenie, któremu puls bije szybko. Bombardowani obrazami mają stałą, niesłabnącą potrzebę odbierania nowych pobudzeń.

2. Zdalna kontrola, np. pilot od telewizora i innych urządzeń, najlepiej symbolizuje ich zachowania, zmiana jest stała, a koncentracja uwagi - kaprysem.

3. Nic ich nie szokuje. Są zmęczeni stale napływającym strumieniem informacji, lecz nie potrafią bez niego żyć (...).

4. Nie ufają dorosłym, a w dziedzinach multimedialnych ich wiedza przekracza wiedzę nauczycieli.

5. Jest to pokolenie prefiguratywne ${ }^{4}$. Następuje odwrócenie ról: dzieci są nauczycielami rodziców; syn uczy ojca, jak obsługiwać komputer, konsolę gier, telefon komórkowy, pomaga mu buszować w Internecie. 
6. Zarazem jest to pokolenie o bardziej tolerancyjnym spojrzeniu na świat, ceniącym różnorodność i odmienność. Bardziej uznaje wartości indywidualizmu (włącznie z uznaniem odpowiedzialności jednostki za swój los), a także bardziej wartości samorządowe niż państwowe.

Dla tego pokolenia, jak wynika z badań przeprowadzonych przez Japończyków, komunikowanie medialne, zwłaszcza on-line, jest łatwiejszą formą niż komunikowanie osobowe face-to-face.

Powyższy cytat zdaje się potwierdzać generalną konkluzję, jaka nasuwa się z zaprezentowanych w niniejszym artykule badań - social media jako przestrzeń, w której ludzie młodzi są dziś niemal codziennie obecni, stają się coraz ważniejszym kanałem komunikacji z tą grupa osób. Warto więc, by wzięli to pod uwagę profesjonalni edukatorzy, osoby zajmujące się zawodowo integracją osób z ograniczoną sprawnością, liderzy opinii, a wreszcie sami niepełnosprawni zainteresowani zmianą postaw społecznych wobec własnego środowiska.

\section{Bibliografia}

Barbour R. (2011), Badania fokusowe, Wydawnictwo Naukowe PWN, Warszawa.

Brewer M.B. (1999), Kiedy stereotypy powodują stereotypizację: wptyw stereotypów na spostrzeganie osób [w:] Stereotypy i uprzedzenia, C.N. Macrae, Ch. Stangor, M. Hewstone (red.), Gdańskie Wydawnictwo Psychologiczne, Gdańsk, s. 208-224.

Bugental J.F.T. (1978), W poszukiwaniu autentyczności [w:] Przełom w psychologii, K. Jankowski (red.),, Czytelnik, Warszawa, s. 325-340.

Celiński P. (2009), Technologizacja więzi społecznych [w:] Wspótczesne media. Status. Aksjologia. Funkcjonowanie, t. 2, I. Hofman, D. Kępa-Figrua (red.), Wydawnictwo Uniwersytetu Marii Curie-Skłodowskiej, Lublin, s. 258-264.

Dobek-Ostrowska B. (2004). Podstawy komunikowania społecznego, Wydawnictwo Astrum, Wrocław.

Gajda J. (2004), Media w edukacji, Oficyna Wydawnicza „Impuls”, Kraków.

Goban-Klas T. (2011), Pokolenie SMS-u w rozwiniętym społeczeństwie informacyjnym [w:] Wartki nurt mediów. Ku nowym formom społecznego życia informacji, T. Goban-Klas (red.), Universitas, Kraków.

Hall C.S., Lindzey G. (1994), Teorie osobowości, Wydawnictwo Naukowe PWN, Warszawa. Hulewska A. (2014), Trudna lekcja tolerancji, „Psychologia w szkole”, vol. 5(46), s. 65-72. Internauci 2014, Komunikat z badań CBOS, nr 82, s. 1.

Konarska M. (1994), Postawy młodzieży polskiej wobec niepetnosprawnych rówieśników [w:] Problemy integracji i edukacji osób niepetnosprawnych, J. Fenczyn, J. Wyczesany (red.), Zarząd Główny Polskiego Stowarzyszenia Osób Niepełnosprawnych: Ostoja, Kraków, s. 25-36.

Kossewska J. (2003), Społeczeństwo wobec osób niepetnosprawnych - postawy i determinanty, Studia Psychologica, I, Annales Academiae Pedagogicae Cracoviensis, folia 14, s. 1-11.

$\overline{4}$ M. Mead (1978), Kultura i tożsamość, Warszawa 1978, s. 60-147. 
Kowalik S. (2007), Psychologia rehabilitacji, Wydawnictwa Akademickie i Profesjonalne, Warszawa.

Levinson P. (2010), Nowe media, Wydawnictwo WAM, Kraków.

Lister M., Dovey J., Giddings S., Grant I., Kelly K. (2009), Nowe media. Wprowadzenie, Wydawnictwo Uniwersytetu Jagiellońskiego, Kraków.

McQuail D. (2007), Teoria komunikowania masowego, Wydawnictwo Naukowe PWN, Warszawa.

Mead M. (1978), Kultura i tożsamość, Wydawnictwo Naukowe PWN, Warszawa.

Oszustowicz B. (1995), Integracyjny system kształcenia a stosunek nauczycieli i uczniów szkót masowych do uczniów klas specjalnych [w:] Pomoc pedagogiczna dzieciom niepetnosprawnym, J. Wyczesany (red.), Wydawnictwo Wyższej Szkoły Pedagogicznej, Częstochowa.

Puchalski K. (2012), Internet a możliwości poprawy efektów edukacji zdrowotnej, „Studia Edukacyjne", nr 23, s. 119-139.

Ruść I. (2007), Wizerunek osób z ograniczonq sprawnością w mediach [w:] Osoby z ograniczona sprawnościq na rynku pracy, W: A. Brzezińska, Z. Woźniak, K. Maj (red.), Academica, Warszawa, s. 131-147.

Shih, C. (2012), Era Facebooka, Helion, Gliwice.

Woynarowska B. (2008), Edukacja zdrowotna, Wydawnictwo Naukowe PWN, Warszawa.

Woźniak Z. (2007), Główne bariery aktywności zawodowej osób z ograniczona sprawnościa [w:] Osoby z ograniczoną sprawnością na rynku pracy, A. Brzezińska, Z. Woźniak, K. Maj (red.), Academica, Warszawa, s. 69-84.

Woźniak Z. (2010), Aktywizacja osób niepetnosprawnych w społeczności lokalnej [w:] Edukacja kulturowa. Społeczność - Aktywizacja - Uczenie się, A.W. Brzezińska, A. Hulewska, J. Słomska-Nowak (red.), Wydawnictwo WSZE, Wrocław, s. 59-82.

Źródła internetowe:

http://wearesocial.net/blog/2015/01/digital-social-mobile-worldwide-2015/ [dostęp: 11.04.2016]. 